$\begin{array}{rr}\text { JURNAL } & \\ \text { FIT(1)PATOLOGI } & \text { Volume } 10, \text { Nomor 5, Oktober } 2014 \\ \text { I N D O N E IA } & \text { DOI: } 10.14692 / \text { jfi. } 10.5 .153\end{array}$

\title{
Formula Pelet Berbahan Aktif Trichoderma sp. dan Aplikasinya terhadap Penyakit Rebah Kecambah pada Tanaman Mentimun
}

\section{Pellet Formulation with Active Material of Trichoderma sp. for Controlling Damping Off Disease in Cucumber Plants}

\author{
Bonny Poernomo Wahyu Soekarno ${ }^{1 *}$, Surono $^{2}$, Susanti $^{1}$ \\ ${ }^{1}$ Institut Pertanian Bogor, Bogor 16680 \\ ${ }^{2}$ Balai Penelitian Tanah, Bogor 16114
}

\begin{abstract}
ABSTRAK
Mentimun (Cucumis sativus) merupakan salah satu komoditas pertanian yang penting di Indonesia, namun tingkat produksi mentimun masih rendah. Salah satu penyebab rendahnya produktivitas mentimun ialah gangguan penyakit tanaman. Penyakit rebah kecambah sering menimbulkan kerugian pada tanaman mentimun yang disebabkan oleh cendawan tular tanah Pythium sp. Upaya pengendaliannya diantaranya ialah dengan menggunakan agens hayati Trichoderma. Meskipun demikian dalam pemanfaatannya tidak praktis sehingga sulit diaplikasikan di lapangan. Formula pelet adalah salah satu alternatif yang lebih praktis untuk diaplikasikan karena berukuran kecil dan mudah dipindahkan. Tujuan penelitian ini ialah membuat formula pelet berbahan aktif Trichoderma dari bahan pembawa yang bernutrisi tinggi, murah, dan mudah. Penelitian ini menggunakan dua uji, yaitu uji in vitro dan in vivo. Uji in vitro dilakukan menggunakan enam formula pelet DAT, UAT, TAT, PAT, DDS and ATS. Formula pelet terbaik pada uji in vitro yaitu UAT dan DDS, kemudian digunakan dalam uji in vivo. Dua formula pelet tersebut mampu menekan serangan cendawan patogen Pythium pada uji in vivo.
\end{abstract}

Kata kunci: pengendalian hayati, Pythium, uji invitro, uji in vivo

\begin{abstract}
Cucumber (Cucumis sativus) is an important vegetable comodity in Indonesia, but its production rate is still low. One of the factors that cause the low productivity is plant diseases. Damping-off disease often causes the damage of cucumber plant caused by a fungus that lives in the soil as soilborne disease, Phytium sp. The controlling effort of this disease have been done, for example using Trichoderma sp. as bio-agent, but the utilization of the bio-agent still is not practical so it is difficult to be applied in field. The pellet formula is more effective to be implemented because of the small size and easily moved. The purpose of this research was to produce the pellet formulation with active material of Trichoderma sp. with rich nutritious content, cheap and easy carrier. This research used two tests, in vitro and in vivo test. The in vitro test used six different pellet formulations, DAT, UAT, TAT, PAT, DDS and ATS. The best formulation in in vitro test are UAT and DDS, then the formulas were used in in vivo test. Both formulas could suppress the pathogenic fungus, Pythium, in vivo test.
\end{abstract}

Key words: bio-controlling, in vitro test, in vivo test, Pythium

*Alamat penulis korespondensi: Departemen Proteksi Tanaman, Fakultas Pertanian, Institut Pertanian Bogor, Kampus Darmaga, Jalan Kamper, Bogor

Tel: 0251-8629364 Faks: 0251-8629362 Surel: bonnypws@gmail.com 


\section{PENDAHULUAN}

Rebah kecambah yang disebabkan oleh cendawan tular tanah Pythium merupakan penyakit yang menimbulkan kerugian pada tanaman mentimun (Cucumis sativus). Cendawan tersebut dapat menyebabkan kematian benih yang baru ditanam, juga menyerang perakaran dan batang yang belum muncul ataupun yang baru muncul ke permukaan tanah. Serangannya lebih parah bila didukung oleh kelembapan tanah yang tinggi (Suleiman dan Emmua 2009).

Upaya untuk mengendalikan penyakit rebah kecambah telah banyak dilakukan, diantaranya ialah menggunakan Trichoderma sebagai agens hayati karena keunggulannya dapat mematikan patogen. Meskipun demikian masih perlu diupayakan cara aplikasi Trichoderma sebagai agens hayati yang efektif dan praktis.

Dalam pengendalian penyakit tanaman, Trichoderma sp. diaplikasikan dalam bentuk pelbagai substrat, misal dedak padi, kulit sekam, serbuk gergaji, tepung kulit sekam, tepung jagung, dan campuran beberapa substrat. Aplikasi Trichoderma dalam bentuk substrat kurang praktis karena membutuhkan wadah dan tenaga kerja yang cukup banyak, serta sering mengalami kendala untuk dibawa dan diaplikasikan di lapangan. Oleh karena itu, perlu dicari formula pelet Trichoderma yang lebih praktis, efektif, dan efisien.

Berbagai bahan pembawa yang dapat digunakan dalam formula pelet ialah dedak, tepung ubi jalar, tepung talas, dan tepung pisang. Bahan tersebut kaya karbohidrat. Selain karbohidrat, cendawan memerlukan asupan protein untuk pertumbuhannya. Oleh karena itu, untuk memperkaya formula pelet Trichoderma dapat ditambahkan ampas tahu yang merupakan hasil samping pembuatan tahu, kadar proteinnya cukup tinggi, yaitu sebesar 26.6\% pada kadar air 9\% (Direktorat Gizi dan Kesehatan 1993).

Tujuan penelitian ialah membuat formula pelet berbahan aktif Trichoderma dengan bahan pembawa yang bernutrisi tinggi, murah, dan mudah diperoleh.

\section{BAHAN DAN METODE}

Pembuatan pelet menggunakan cendawan Trichoderma sp. koleksi dari Laboratorium Mikrobiologi Tanah, Balai Penelitian Tanah Cimanggu Bogor. Trichoderma sp. ini diremajakan pada medium agar-agar dekstrose kentang (ADK).

Bahan membuat pelet terdiri atas tepung talas, ubi jalar, pisang, dan bawang putih dengan bobot yang sama. Semua bahan dikupas kulitnya, dicuci, kemudian ditiriskan sekitar 5 menit. Bahan dipotong tipis-tipis untuk mempercepat proses penjemuran dibawah sinar matahari yang selanjutnya digiling hingga menjadi tepung yang halus.

Pembuatan tepung ampas tahu lebih sederhana, yaitu dengan menjemur ampas tahu yang masih basah dan segar hingga kering tidak lengket satu sama lain, kemudian digiling dan disaring hingga menjadi tepung halus.

Penyediaan bahan pembawa dari dedak lebih sederhana karena hanya menyaring dedak hingga diperoleh butiran yang halus. Semua bahan untuk membuat pelet dianalisis kandungan $\mathrm{C}$ dan $\mathrm{N}$-nya untuk menentukan nutrisi yang diperlukan oleh Trichoderma.

\section{Komposisi Formula Pelet}

Bahan penyusun pelet terdiri atas tepung pisang, ubi jalar, talas, dan dedak yang dicampur dengan tepung ampas tahu, tepung bawang putih, molase, dan air steril sesuai keperluan (Tabel 1).

\section{Pembuatan Pelet Trichoderma}

Masing-masing bahan pembawa dengan komposisi yang telah ditentukan ditambah $1.5 \mathrm{~g}$ tepung bawang putih yang berfungsi sebagai antibiotik. Bahan pembawa tersebut dibungkus menggunakan kertas alumunium, kemudian disterilkan dalam autoklaf.

Trichoderma berumur 7 hari pada medium PDA dibuat suspensinya dan diencerkan sampai kerapatan massa konidium $2.57 \times 10^{8}$. Sebanyak $10 \mathrm{~mL}$ suspensi konidium ini dimasukkan ke dalam campuran bahan pelet, kemudian ditambahkan $15 \mathrm{~mL}$ molase dan 
Tabel 1 Komposisi bahan pembawa pelet

\begin{tabular}{llccccc}
\hline Formula & \multicolumn{2}{c}{ Tepung $(\mathrm{g})$} & Ampas tahu $(\mathrm{g})$ & Bawang putih $(\mathrm{g})$ & Molase $(\mathrm{mL})$ & Air steril $(\mathrm{mL})$ \\
\hline DAT & Dedak & 31.0 & 10.5 & 1.5 & 15 & 42 \\
UAT & Ubi Jalar & 12.0 & 19.5 & 1.5 & 15 & 52 \\
TAT & Talas & 17.0 & 24.5 & 1.5 & 15 & 42 \\
PAT & Pisang & 17.0 & 24.5 & 1.5 & 15 & 42 \\
DDS & Dedak & 41.5 & 0.0 & 1.5 & 15 & 42 \\
ATS & & & 41.5 & 1.5 & 15 & 52 \\
\hline
\end{tabular}

DAT, dedak dan ampas tahu; UAT, tepung ubi jalar dan ampas tahu; TAT, tepung talas dan ampas tahu; PAT, tepung pisang dan ampas tahu; DDS, dedak saja; ATS; ampas tahu saja.

air steril sesuai komposisi masing-masing medium dan diaduk hingga homogen. Campuran ini dimasukkan ke dalam sedotan plastik steril berdiameter $1 \mathrm{~cm}$ dan panjang $1 \mathrm{~cm}$ dan dipadatkan. Butiran pelet dalam sedotan tersebut dikeringkan dibawah lampu $40 \mathrm{~W}$ di dalam kardus dengan aerasi dari kipas angin selama 7 hari. Selanjutnya pelet Trichoderma dikeluarkan dari sedotan dan dimasukkan ke kantong plastik. Proses pembuatan pelet dilakukan didalam ruang laminar secara aseptik.

Uji Pertumbuhan Trichoderma sp. dalam Pelet

Uji untuk menentukan daya hidup Trichoderma yang ada di dalam pelet dilakukan secara in vitro pada 6 formula pelet: DAT, UAT, TAT. PAT, DDS, dan ATS.

Sebutir pelet diletakkan pada medium ADK di dalam cawan dan diinkubasi selama 7 hari pada suhu ruang. Setiap formula pelet diulang sebanyak 5 kali. Pengamatan dilakukan dengan mengukur diameter koloni Trichoderma setiap hari.

\section{Penyiapan Tanah sebagai Medium Tumbuh pada Uji in Vivo}

Uji ini menggunakan tanah yang berasal dari lahan pertanaman mentimun di Kampung Ciletuh Girang, Kecamatan Cigombong, Kabupaten Bogor. Tanah diinfestasi dengan Pythium sp., patogen penyebab rebah kecambah pada mentimun.

Buah mentimun disterilkan permukaannya menggunakan alkohol 70\% kemudian dipotong melintang menjadi 2 bagian. Selanjutnya setiap potongan buah mentimun diletakkan pada permukaan tanah di dalam gelas plastik. Posisi buah mentimun yang berada dipermukaan tanah adalah bagian yang dipotong. Potongan buah mentimun diinkubasi pada suhu dan kelembapan ruang selama 4 hari, setiap hari diamati secara mikroskopi untuk memastikan infestasi Pythium sp. pada tanah tersebut.

\section{Uji Formula Pelet Trichoderma sp. secara in Vivo}

Berdasarkan uji secara in vitro, dipilih 2 formula pelet yang menunjukkan pertumbuhan koloni Trichoderma sp. paling cepat. Hasil uji tersebut akan diuji secara in vivo.

Uji Trichoderma sp. dalam formula pelet yang dilakukan secara in vivo terdiri atas 7 perlakuan: kontrol positif ialah tanah steril dari tanah endemik; kontrol negatif ialah tanah yang terinfestasi Pythium sp.; tanah terinfestasi Pythium sp. dan kompos; tanah terinfestasi Pythium sp. + pelet ubi jalar + ampas tahu (UAT); tanah terinfestasi Pythium sp. + kompos + pelet UAT; tanah terinfestasi Pythium sp. + pelet dedak (DDS); dan tanah terinfestasi Pythium sp. + kompos + pelet DDS.

Formula pelet ditanam pada medium tanah yang telah dicampur dengan kompos dan medium tanah yang tidak dicampur dengan kompos, kemudian medium tumbuh tersebut diinkubasi selama 7 hari, demikian juga pada perlakuan medium tanah yang dicampur dengan kompos saja tanpa formula pelet. Sebanyak 50 g medium tanam (tanah yang dicampur dengan kompos dan tanah saja) dimasukkan ke dalam pipa paralon berukuran panjang $10 \mathrm{~cm}$ dan diameter $4 \mathrm{~cm}$. Selanjutnya sebanyak 3 butir pelet DDS $( \pm 0.5 \mathrm{~g})$ dan 4 butir pelet UAT $( \pm 0.5 \mathrm{~g})$ ditanam ke dalam 
medium tumbuh tersebut, sedangkan pada kontrol tidak ditanami formula pelet tersebut. Masing-masing perlakuan diulang sebanyak 5 kali dan setiap ulangan terdiri atas 5 paralon, yang ditanami 1 butir benih mentimun.

Perbandingan formula pelet Trichoderma sp. yang diaplikasikan untuk medium dengan bobot $50 \mathrm{~g}$ ialah $0.5 \mathrm{~g}$. Formula pelet UAT mempunyai bobot $0.148 \mathrm{~g}$ per butir sehingga formula pelet UAT yang diaplikasikan sebanyak 4 butir per paralon dengan total bobot $0.592 \mathrm{~g}$.

Formula pelet DDS yang diaplikasikan sebanyak 3 butir per paralon, karena 1 butir formula pelet DDS mempunyai bobot lebih berat daripada 1 butir formula pelet UAT. Formula pelet DDS mempunyai bobot $0.195 \mathrm{~g}$ per butir sehingga hanya digunakan 3 butir formula pelet DDS, yaitu seberat $0.585 \mathrm{~g}$.

\section{Rancangan Percobaan}

Penelitian ini terdiri atas uji in vitro dan uji in vivo. Uji in vitro disusun dalam 6 perlakuan dengan 5 ulangan. Peubah yang diamati adalah pertumbuhan Trichoderma sp. pada formula pelet yang diinkubasi pada cawan petri. Uji in vivo disusun dalam 7 perlakuan dengan 5 ulangan. Peubah yang diamati adalah jumlah benih yang tumbuh. Kedua uji tersebut disusun dalam rancangan acak lengkap.

Data hasil pertumbuhan Trichoderma sp. pada uji in vitro dan jumlah benih yang tumbuh pada uji in vivo dianalisis menggunakan SAS dan pembandingan nilai tengah dengan selang berganda duncan pada taraf 5\%.

\section{HASIL}

\section{Formula Pelet secara in Vitro}

Berdasarkan hasil penelitian, pertumbuhan koloni Trichoderma sp. pada beberapa formula pelet yang disimpan selama 7 hari dan 14 hari, berbeda nyata dengan kontrol (Tabel 2 dan 3). Secara in vitro formula pelet dengan masa simpan 7 hari menunjukkan pertumbuhan koloni Trichoderma sp. yang paling cepat berturut-turut pada formula pelet DAT, DDS, TAT, UAT, PAT, dan ATS. Formula pelet yang masih tumbuh dengan baik pada penyimpanan 14 hari berturut-turut ialah DDS, TAT, UAT, DAT, PAT, dan ATS. Berdasarkan uji formula pelet dengan masa simpan 7 hari dan 14 hari, komposisi bahan pembawa yang paling baik untuk dijadikan substrat pelet Trichoderma sp. ialah pelet DDS. Hal ini didasarkan pada kecepatan pertumbuhan koloni Trichoderma sp. dari beberapa formula pelet dengan masa simpan 14 hari selama 7 hari pengamatan (Tabel 3). Urutan formula pelet dari yang paling baik untuk dijadikan substrat menurut hasil penelitian berturut-turut ialah pelet DDS, TAT, UAT, DAT, dan PAT.

\section{Uji FormulaPelet secara in Vivo}

Penambahan formula pelet DDS dan UAT ke dalam medium tumbuh yang telah terinfestasi Pythium sp. dapat meningkatkan kemampuan benih mentimun berkecambah dan tumbuh dibandingkan dengan kontrol negatif(Table 4). Hal ini menunjukkan aplikasi Trichoderma sp. sebagai agens hayati dalam

Tabel 2 Diameter koloni Trichoderma sp. pada beberapa bahan pembawa pelet selama masa simpan 7 hari

\begin{tabular}{lccccccc}
\hline \multirow{2}{*}{ Bahan pelet } & \multicolumn{7}{c}{ Rata-rata diameter koloni Trichoderma } \\
\cline { 2 - 8 } & 1 & 2 & 3 & 4 & 5 & 6 & 7 \\
\hline DAT & $0.24 \mathrm{~b}$ & $4.36 \mathrm{a}$ & $7.30 \mathrm{a}$ & $9.00 \mathrm{a}$ & $9.00 \mathrm{a}$ & $9 \mathrm{a}$ & $9 \mathrm{a}$ \\
UAT & $0.00 \mathrm{~b}$ & $1.31 \mathrm{~b}$ & $6.32 \mathrm{bc}$ & $8.75 \mathrm{bc}$ & $8.99 \mathrm{a}$ & $9 \mathrm{a}$ & $9 \mathrm{a}$ \\
TAT & $0.00 \mathrm{~b}$ & $1.12 \mathrm{~b}$ & $6.37 \mathrm{bc}$ & $8.93 \mathrm{ab}$ & $9.00 \mathrm{a}$ & $9 \mathrm{a}$ & $9 \mathrm{a}$ \\
PAT & $0.00 \mathrm{~b}$ & $0.00 \mathrm{c}$ & $5.85 \mathrm{c}$ & $8.70 \mathrm{c}$ & $9.00 \mathrm{a}$ & $9 \mathrm{a}$ & $9 \mathrm{a}$ \\
DDS & $1.41 \mathrm{a}$ & $4.98 \mathrm{a}$ & $6.70 \mathrm{ab}$ & $8.95 \mathrm{a}$ & $9.00 \mathrm{a}$ & $9 \mathrm{a}$ & $9 \mathrm{a}$ \\
ATS & $0.00 \mathrm{~b}$ & $2.07 \mathrm{~b}$ & $4.11 \mathrm{~d}$ & $7.49 \mathrm{~d}$ & $8.63 \mathrm{~b}$ & $9 \mathrm{a}$ & $9 \mathrm{a}$ \\
Kontrol & $0.00 \mathrm{~b}$ & $0.00 \mathrm{c}$ & $0.00 \mathrm{e}$ & $0.00 \mathrm{e}$ & $0.00 \mathrm{c}$ & $0 \mathrm{~b}$ & $0 \mathrm{~b}$ \\
\hline
\end{tabular}

*Angka pada kolom yang sama yang diikuti oleh huruf yang sama tidak berbeda nyata menurut uji selang berganda Duncan pada taraf $5 \%$.

DAT, dedak dan ampas tahu; UAT, tepung ubi jalar dan ampas tahu; TAT, tepung talas dan ampas tahu; PAT,tepung pisang dan ampas tahu; DDS, dedak saja; dan ATS, ampas tahu saja. 
Tabel 3 Diameter koloni Trichoderma sp. dari beberapa bahan pembawa pelet selama masa simpan 14 hari

\begin{tabular}{lccccccc}
\hline \multirow{2}{*}{ Perlakuan } & \multicolumn{7}{c}{ Rata-rata diameter koloni Trichoderma sp. pada hari ke-*(cm) } \\
\cline { 2 - 8 } & 1 & 2 & 3 & 4 & 5 & 6 & 7 \\
\hline DAT & $0.00 \mathrm{a}$ & $0 \mathrm{~b}$ & $2.77 \mathrm{c}$ & $6.46 \mathrm{c}$ & $9.00 \mathrm{a}$ & $9 \mathrm{a}$ & $9 \mathrm{a}$ \\
UAT & $0.00 \mathrm{a}$ & $0 \mathrm{~b}$ & $3.34 \mathrm{bc}$ & $7.01 \mathrm{~b}$ & $9.00 \mathrm{a}$ & $9 \mathrm{a}$ & $9 \mathrm{a}$ \\
TAT & $0.00 \mathrm{a}$ & $0 \mathrm{~b}$ & $3.82 \mathrm{~b}$ & $7.31 \mathrm{~b}$ & $9.00 \mathrm{a}$ & $9 \mathrm{a}$ & $9 \mathrm{a}$ \\
PAT & $0.00 \mathrm{a}$ & $0 \mathrm{~b}$ & $2.81 \mathrm{c}$ & $6.25 \mathrm{c}$ & $9.00 \mathrm{a}$ & $9 \mathrm{a}$ & $9 \mathrm{a}$ \\
DDS & $0.33 \mathrm{a}$ & $3 \mathrm{a}$ & $6.31 \mathrm{a}$ & $9.00 \mathrm{a}$ & $9.00 \mathrm{a}$ & $9 \mathrm{a}$ & $9 \mathrm{a}$ \\
ATS & $0.00 \mathrm{a}$ & $0 \mathrm{~b}$ & $3.08 \mathrm{c}$ & $6.44 \mathrm{c}$ & $8.52 \mathrm{~b}$ & $9 \mathrm{a}$ & $9 \mathrm{a}$ \\
Kontrol & $0.00 \mathrm{a}$ & $0 \mathrm{~b}$ & $0.00 \mathrm{~d}$ & $0.00 \mathrm{~d}$ & $0.00 \mathrm{c}$ & $0 \mathrm{~b}$ & $0 \mathrm{~b}$ \\
\hline
\end{tabular}

*Angka pada kolom yang sama yang diikuti oleh huruf yang sama tidak berbeda nyata menurut uji selang berganda Duncan pada taraf $5 \%$.

DAT, dedak dan ampas tahu; UAT, tepung ubi jalar dan ampas tahu; TAT, tepung talas dan ampas tahu; PAT, tepung pisang dan ampas tahu; DDS, dedak saja: ATS, ampas tahu saja.

Tabel 4 Jumlah benih mentimun yang tumbuh pada pengujian formula pelet dedak (DDS) dan ubi jalar dan ampas tahu (UAT) dengan masa simpan 7 hari secara in vivo

\begin{tabular}{lrrc}
\hline \multirow{2}{*}{ Perlakuan } & \multicolumn{3}{c}{ Benih mentimun yang tumbuh pada } \\
& \multicolumn{3}{c}{ hari ke- $(\%)$} \\
\cline { 2 - 4 } & 5 & 6 & 7 \\
\hline Tanah terinfestasi Pythium sp. (kontrol negatif) & 60 & 56 & 56 \\
Tanah steril (kontrol positif) & 80 & 80 & 96 \\
Tanah terinfestasi Pythium sp. + kompos & 76 & 80 & 80 \\
Tanah terinfestasi Pythium sp. + pelet UAT & 88 & 88 & 84 \\
Tanah terinfestasi Pythium sp. + kompos + pelet UAT & 88 & 88 & 80 \\
Tanah terinfestasi Pythium sp. + pelet DDS & 88 & 88 & 88 \\
Tanah terinfestasi Pythium sp. + kompos + pelet DDS & 88 \\
\hline
\end{tabular}

bentuk formula pelet DDS dan UAT mampu menekan pertumbuhan Pythium sp. patogen penyebab rebah kecambah (damping off) pada tanaman mentimun.

\section{PEMBAHASAN}

Trichoderma sp. merupakan agens hayati yang sudah banyak digunakan dalam perlindungan tanaman, baik sebagai pupuk hayati ataupun sebagai agens pengendali penyakit, tetapi pemanfaatannya kurang praktis jika diaplikasikan di lapangan, karena memerlukan wadah yang cukup banyak dan tenaga kerja banyak. Penggunaan cendawan antagonis sebagai agens hayati harus dalam bentuk formula yang tepat dengan bahan yang mudah tersedia (Lewis dan Papavizas 1991). Oleh karena itu, formula Trichoderma sp. dikembangkan dalam bentuk pelet dari beberapa bahan pembawa yang cocok sebagai substrat. Formula pelet ini berukuran kecil sehingga lebih praktis untuk dibawa atau dikirim dan diaplikasikan di lapangan.

Keefektifan masing-masing formula pelet dipengaruhi oleh kandungan $\mathrm{C} / \mathrm{N}$ dan faktor lain pada masing-masing bahan pembawa. Pada penyimpanan perlu diperhatikan kondisi lingkungan agar spora cendawan dapat bertahan lama. Faktor lingkungan yang mempengaruhi umur penyimpanan cendawan dibedakan menjadi faktor intrinsik dan faktor ekstrinsik. Arbianto (1980) menjelaskan faktor intrinsik terdiri atas jumlah $\mathrm{C} / \mathrm{N}$ medium, struktur biologi, bahan baku dan kandungan air. Faktor ekstrinsik meliputi $\mathrm{pH}$, suhu inkubasi, kelembapan, potensi terjadinya oksidasi reduksi, ketersediaan oksigen serta aerasi. Penentuan komposisi formula pelet didasarkan atas kebutuhan $\mathrm{C} / \mathrm{N}$ untuk pupuk hayati. Berdasarkan syarat mutu yang ditetapkan dalam Peraturan Menteri Pertanian No 28/Permentan/SR.130/5/2009 tentang persyaratan teknis minimal pupuk organik 
atau pupuk hayati (Kemetan 2009), indikator yang digunakan adalah $\mathrm{pH}$, kandungan C-organik, N-total, C/N, unsur makro dan mikro. Perbandingan $\mathrm{C} / \mathrm{N}$ yang dipersyaratkan ialah $<25$.0.

Dedak merupakan sumber nutrisi yang digunakan untuk memacu pertumbuhan dan perkembangan cendawan. Dedak ditambahkan untuk meningkatkan nutrisi medium tanam sebagai sumber karbohidrat, karbon, dan nitrogen. Dedak mengandung protein dan lemak serta serat kasar. Ampas tahu adalah limbah industri yang berbentuk padatan dari kedelai yang diperas sebagai sisa dalam pembuatan tahu yang ketersediaanya cukup banyak, murah, dan mudah didapat. Berdasarkan pada bahan kering ampas tahu mengandung lemak $5.52 \%$, serat kasar 17.06\%, dan BETN 45.44\% (Nuraini et al. 2009). Kadar protein ampas tahu cukup tinggi, yaitu sebesar $26.6 \%$, pada kadar air 9\% (Direktorat Gizi dan Kesehatan 1993), sehingga dapat dijadikan sumber protein pada formula pelet.

Formula pelet DDS mempunyai kandungan $\mathrm{C} / \mathrm{N}$ sebesar 26.67. Nilai kandungan $\mathrm{C} / \mathrm{N}$ pada formula pelet DDS lebih tinggi daripada batas yang ditetapkan Permentan, namun kualitas pertumbuhan koloni Trichoderma sp. menjadi lebih baik dibandingkan dengan formula pelet lain dengan $\mathrm{C} / \mathrm{N}$ yang sesuai standar mutu berdasarkan ketetapan Permentan no 28 tahun 2009. Pupuk hayati dari Trichoderma sp. pada bahan pembawa dedak ini perlu diuji ulang untuk penetapan batas nisbah C/N-nya .

Formula pelet ATS mempunyai kandungan $\mathrm{C} / \mathrm{N}$ lebih kecil daripada standar mutu yang ditentukan Permentan no 28 tahun 2009,yaitu sebesar 16.52. Hasil pengujian secara in vitro menunjukkan bahwa pertumbuhan koloni Trichoderma sp. sangat lambat dibandingkan dengan formula pelet lain yang mempunyai kandungan $\mathrm{C} / \mathrm{N}$ sesuai dengan standar mutu yang ditentukan Permentan. Hal ini disebabkan kandungan $\mathrm{C} / \mathrm{N}$ pada ampas tahu tidak mencukupi kebutuhan nutrisi bagi pertumbuhan Trichoderma sp. sehingga pertumbuhannya menjadi terhambat. Oleh karena itu, ampas tahu tidak cocok untuk dijadikan substrat tunggal pada formula Trichoderma sp.. Pemanfaatan ampas tahu sebagai sumber protein dalam pembuatan formula pelet Trichoderma sp. sebaiknya dipadukan dengan bahan pembawa lain yang sesuai.

Kandungan $\mathrm{C} / \mathrm{N}$ pada formula pelet TAT, UAT, DAT, dan PAT sesuai dengan standar mutu yang ditetapkan Permentan dan menunjukkan sebagai substrat yang baik untuk cendawan uji. Meskipun demikian, masing-masing bahan pembawa pelet TAT, UAT, dan PAT menunjukkan perbedaan terhadap pertumbuhan Trichoderma sp yang disebabkan oleh perbedaan kandungan air masing-masing bahan pembawa. Dedak mempunyai kandungan air yang lebih tinggi dibandingkan dengan tepung ubi, pisang, talas, dan ampas tahu. Tepung talas dan tepung ubi mempunyai kandungan air yang hampir sama, tetapi lebih besar daripada kandungan air pada tepung pisang dan ampas tahu. Tepung ampas tahu mempunyai kandungan air yang paling sedikit dibandingkan dengan bahan pembawa lainnya pada perlakuan ini. Formula pelet TAT hasilnya lebih baik dibandingkan dengan formula pelet UAT dan PAT sebagai substrat atau bahan pembawa Trichoderma sp., sedangkan formula pelet UAT lebih baik daripada formula pelet PAT.

Formula pelet yang dipilih untuk uji in vivo ialah formula pelet DDS dan UAT. Hasil uji in vitro, menunjukkan formula pelet DDS merupakan yang paling baik untuk dijadikan substrat karena pada substrat tersebut pertumbuhan diameter koloni Trichoderma sp. paling cepat dibandingkan dengan formula pelet yang lain. Formula pelet DDS juga menggunakan bahan baku yang murah dan mudah dicari sehingga dapat dengan mudah untuk diaplikasikan oleh petani. Formula pelet TAT dan UAT juga menunjukkan sebagai substrat yang baik untuk pertumbuhan koloni Trichoderma sp., meskipun diantara kedua formula pelet tersebut tidak berbeda nyata menurut uji statistik. Ketersediaan bahan baku untuk formula pelet TAT sulit didapat karena spesifik daerah dan harga bahan baku pada formula pelet TAT lebih mahal daripada 
formula pelet UAT. Dengan demikian formula pelet UAT dan DDS dipilih untuk digunakan pada uji in vivo karena lebih efektif, murah, dan mudah diperoleh.

Hasil pengujian secara in vivo menunjukkan bahwa pada kontrol negatif, jumlah benih mentimun yang tumbuh lebih sedikit dibandingkan dengan kontrol positif dan berbeda nyata menurut uji statistik dari hari ke-5 sampai ke-7 setelah tanam. Berdasarkan pengamatan cendawan patogen Pythium sp. dalam tanah menyebabkan benih mentimun gagal berkecambah atau terhambat pertumbuhannya. Cendawan patogen tersebut dapat menyerang dan menyebabkan kematian pada benih yang baru ditanam, bahkan sering menyerang perakaran dan batang yang belum muncul ataupun yang baru muncul ke permukaan tanah (Agrios 2005). Secara umum, perlakuan formula pelet DDS dan UAT menyebabkan benih mentimun yang tumbuh lebih banyak dan berbeda nyata dibandingkan dengan kontrol negatif. Hal ini menunjukkan aplikasi formula pelet DDS dan UAT mampu menekan perkembangan Pythium sp.. Beberapa perlakuan pada pengujian in vivo yaitu pada perlakuan tanah terinfestasi $P$ ythium sp. + kompos dan tanah terinfestasi Pythium sp. + pelet UAT, pada hari ke-5 sampai ke-7 menunjukkan jumlah benih mentimun yang tumbuh tidak berbeda nyata dengan kontrol positif, begitu juga penggunaan kompos pada perlakuan tersebut. Bahan organik (kompos) memiliki fungsi penting dalam budidaya tanaman, yaitu fungsi biologi sebagai sumber energi utama bagi aktivitas jasad renik tanah.

Berdasarkan hal tersebut, pelet UAT dan kompos cukup efektif untuk menekan cendawan patogen Pythium sp. Sama halnya dengan perlakuan pada tanah terinfestasi Pythium sp. + kompos + pelet UAT, tanah terinfestasi Pythium sp. + pelet DDS, dan tanah terinfestasi Pythium sp. + kompos + pelet DDS, beberapa perlakuan tersebut menunjukkan bahwa jumlah benih yang tumbuh tidak berbeda nyata menurut uji statistik terhadap kontrol positif. Hal ini juga menunjukkan bahwa penggunaan pelet DDS cukup efektif untuk menekan pertumbuhan Pythium sp. penyebab damping off.

Formula pelet dari DDS dan formula pelet UAT merupakan substrat tumbuh yang baik bagi agens hayati untuk pengendalian penyakit rebah kecambah pada tanaman mentimun yang disebabkan oleh Pythium sp..

\section{DAFTAR PUSTAKA}

Agrios GN. 2005. Plant Pathology. Burlington (CA): Elsevier Academic Press.

Arbianto P. 1980. The Indigenous Fermented Food Process. Kumpulan Paper Fermented Food II. Bogor (ID): Pusbangtepa IPB.

Direktorat Gizi dan Kesehatan RI. 1993. Daftar Komposisi Bahan Makanan. Jakarta (ID): Bharata Karya Aksara.

[Kementan] Kementrian Pertanian. 2009. Peraturan Menteri Pertanian(Permentan) No 28/Permentan/ SR.130/5/2009 tentang persyaratan teknis minimal pupuk organik atau pupuk hayati. Jakarta (ID): Kementrian Pertanian.

Lewis JA, Papavizas GC. 1983. Production of Clamyidospores and Conidia by Trichoderma $s p$. In Liquid and Solid Growth Medium. Soil Biol Biochem. 15(4):351-357. DOI: http://dx.doi. org/10.1016/0038-0717(83)90083-4.

Nuraini SA, Latif, Sabrina. 2009. Improving the quality of tapioka by paoduct thrugh fermentation by Neurospora crassa to produce $\beta$ caroten rich feed. Pak J Nutr. 8(4):487-490. DOI: http://dx.doi. org/10.3923/pjn.2012.605.608.

Suleiman MN, Emua SA. 2009. Efficacy of four plant extracts in the control of root rot. disease cowpea (Vigna unguiculata (L.) Walp). Afr J Biotechnol. 8(16):38063808. 